\title{
Expression, Purification, Characterization and In Vitro Activity of Recombinant Mouse Cu/Zn-Binding Superoxide Dismutase (mSOD1)
}

\author{
Zide Zhang ${ }^{1,2}$, Luyuan Huang ${ }^{3}$, Zhihui Luo ${ }^{1}$, Yong Liu ${ }^{4}$, Aiyun Li ${ }^{1}$, Hua Sun ${ }^{1}$, \\ Qiuhong Wu $^{1}$, Renwang Jiang ${ }^{1,2,5}$ and Feng Wang \\ ${ }^{1}$ College of Pharmacy, ${ }^{2}$ Guangdong Province Key Laboratory of Pharmacodynamic Constituents of TCM and New Drugs \\ Research, Jinan University, Guangzhou 510632, ${ }^{3}$ South China Institute for Stem Cell Biology and Regenerative Medicine, \\ Guangzhou Institute of Biomedicine and Health, Chinese Academy of Sciences, Guangzhou 510633, ${ }^{4}$ Guangdong Key \\ Laboratory of Agro-Environment Integrated Control, Guangdong Institute of Eco-Environmental and Soil Sciences, Guangzhou \\ 510650, ${ }^{5}$ Institute of Traditional Chinese Medicine and Natural Products, Jinan University, Guangzhou 510632, China
}

*For correspondence: Email: novelfunction@163.com; Tel: +86-20-38375022; Fax: +86-20-85224766

Received: 14 October 2012

Revised accepted: 17 May 2013

\begin{abstract}
Purpose: To express, purify and characterize recombinant mouse Cu/Zn-binding superoxide dismutase (mSOD1), and investigate its activity in vitro.

Methods: The protein, $m S O D 1$, was expressed after induction with isopropyl-beta- $D$ thiogalactopyranoside (IPTG). The target protein was purified by Ni-NTA affinity chromatography. The identity of the recombinant protein was confirmed by Western-blot and peptide mass fingerprinting (PMF) analysis. Protein activity in vitro was investigated by SOD activity assay kit and DNA damage protective assay.

Results: $m S O D 1$ protein was expressed with a final yield of about $60 \mathrm{mg}$ of pure protein per liter of culture medium. After purification, the target protein was $>95 \%$. The identity of the recombinant protein was confirmed. SOD activity assay showed that the highest activity of the mSOD1 was $3789.0 \pm 80.5$ $U / \mathrm{mg}$. The present work showed that mSOD1 was effective in protecting DNA from oxidative damage. Conclusion: High purity recombinant $m S O D 1$ was obtained and characterized, and had high activity in vitro. The study indicates that the mSOD1 may serve as a potential therapeutic agent for those diseases caused by oxidative stress.
\end{abstract}

Keywords: Cu/Zn-binding Superoxide dismutase, Expression, Purification, Metal ions, DNA damage

Tropical Journal of Pharmaceutical Research is indexed by Science Citation Index (SciSearch), Scopus, International Pharmaceutical Abstract, Chemical Abstracts, Embase, Index Copernicus, EBSCO, African Index Medicus, JournalSeek, Journal Citation Reports/Science Edition, Directory of Open Access Journals (DOAJ), African Journal Online, Bioline International, Open-J-Gate and Pharmacy Abstracts

\section{INTRODUCTION}

Superoxide dismutase (SOD; EC 1.15.1.1) is a ubiquitous enzyme, which catalyzes the dismutation of the superoxide radical into hydrogen peroxide and molecular oxygen $\left(2 \mathrm{O}_{2}\right.$ $+2 \mathrm{H}^{+} \rightarrow \mathrm{H}_{2} \mathrm{O}_{2}$ ), and plays a central role in protecting against oxidative stress. In the last few years, SOD has been widely used in prevention of oncogenesis and tumor promotion, as well as protection against reperfusion damages of ischemic tissue [1]. According to the metal cofactor present at the catalytic center, multiple SOD isoforms are classified into four types, copper/zinc (Cu/Zn-SOD), nickel (Ni-SOD), manganese (Mn-SOD) and iron (Fe-SOD) forms. $\mathrm{Cu} / \mathrm{Zn}-\mathrm{SOD}$ is generally found in the cytoplasm, chloroplasts, nuclear compartments, and lysosomes of mammalian cells [2, 3], Mn-SOD in mitochondria, whereas Fe-SOD is present within 
the chloroplasts of some plants [4]. Ni-dependent enzymes have only been described from Streptomyces species [5].

Molecular cloning and expression of SOD1 have been reported in various prokaryotic and eukaryotic species, for example, green bamboo[6], Black Porgy [7] and sweet potato [8]. However, no data have been published on SOD1 sequences from mouse expressed with a modified pET-15b vector in E.coli Rosetta-gami cells. Furthermore, there has been no report on expression process optimization and productivity estimation of mouse SOD1. Although, the activity of mSOD1 in vivo has been related to amyotrophic lateral sclerosis $[9,10]$, oxidative stress [11], reactive oxygen species (ROS) [12] and cerebral ischemia [13], most of these studies involved the use of SOD1 cDNA transfection. Due to the absence of mSOD1 expression, there are no reports on mSOD1 activity in vitro, especially, the effect of metal ions on the mSOD1 activity. In addition, the DNA damage protective activity of mSOD1 in vitro has not been investigated.

\section{EXPERIMENTAL}

\section{Reagents}

Sma I, CIAP, $\mathrm{T}_{4}$ DNA ligase and protein marker were purchased from Takara (Osaka, Japan). KOD-plus are from Toybo (Osaka, Japan). E. coli Rosetta-gami strain was from Novagen (Darmstadt, Germany). Mouse anti-His monoclonal antibody was from TIANGEN (Beijing, China). Horseradish peroxidase (HRP) labeled goat anti-mouse lgGs were purchased from Proteintech (Chicago, USA). Ni-NTA resin was from QIAGEN (Hilden, German). SOD activity assay kit was from Jiancheng Bioengineering Institute (Nanjing, China). The other reagents used in this study were of analytical grade and are commercially available.

\section{Construction of expression vector}

Primers (forward: 5'-ATGGCGATGAAAGCGG TG TG-3', reverse:5'- TTACTGCGCAATCC CAATCAC -3') were designed based on the sequence of mSOD1 (Genbank Accession NM_011434.1). The coding sequence of mSOD1 was amplified by PCR, using template cDNA of mouse liver. The amplified PCR product was ligated into a modified pET15b (Sma I) expression vector[14], resulting in the recombinant vector pET15b-mSOD1. The recombinant plasmid constructs were confirmed by direct sequencing (Yinjun, Shanghai, China).
The pET15b-mSOD1 plasmid was transformed into E. coli Rosetta-gami strain for expression.

\section{Protein expression and purification}

A single colony of $E$. coli Rosetta-gami cells bearing pET15b-mSOD1 plasmid was inoculated into $5 \mathrm{ml}$ LB medium containing $100 \mu \mathrm{g} / \mathrm{ml}$ ampicillin. After grown at $37{ }^{\circ} \mathrm{C}$ with shaking at $220 \mathrm{rpm}$ for $12 \mathrm{~h}$, the culture $(2 \mathrm{ml})$ was then inoculated into $200 \mathrm{ml}$ LB medium and grown at $37{ }^{\circ} \mathrm{C}$. At an $\mathrm{OD}_{600}$ of $0.6-0.8$, the culture was induced by adding IPTG to a final concentration of $0.5 \mathrm{mM}$, and incubation was continued for an additional $10 \mathrm{~h}$ at $30^{\circ} \mathrm{C}$. Cells were harvested by centrifugation and resuspended in lysis buffer (50 $\mathrm{mM}$ Tris- $\mathrm{HCl}, 0.2 \mathrm{mM}$ EDTA, $100 \mathrm{mM} \mathrm{NaCl}, 1 \%$ Triton $\mathrm{X}-100,10 \mathrm{mg} / \mathrm{ml}$ lysozyme, $\mathrm{pH}$ 8.0). The cells were disrupted by sonication on ice. The cell suspension was centrifuged at $12,000 \mathrm{rpm}$ for $15 \mathrm{~min}$ at $4{ }^{\circ} \mathrm{C}$.

The supernatant of lysate containing target protein was purified with Ni-NTA affinity chromatography [14]. After filtering with a 0.22 $\mu \mathrm{m}$ filter, the supernatant was loaded onto a $\mathrm{Ni}-$ NTA-His bind column equilibrated with buffer $A$ (20 mM sodium phosphate, $500 \mathrm{mM} \mathrm{NaCl}, 10$ $\mathrm{mM}$ imidazole, $\mathrm{pH} 7.4$ ) at $4{ }^{\circ} \mathrm{C}$. The column was washed with 10 column volumes of buffer $B$ (20mM sodium phosphate, $500 \mathrm{mM} \mathrm{NaCl}, 20 \mathrm{mM}$ imidazole, $\mathrm{pH}$ 7.4). The mSOD1 was eluted with buffer C (20 mM sodium phosphate, $500 \mathrm{mM}$ $\mathrm{NaCl}, 250 \mathrm{mM}$ imidazole, $\mathrm{pH}$ 7.4). The proteincontaining fractions were pooled and dialyzed overnight against a buffer containing $20 \mathrm{mM}$ sodium phosphate, $500 \mathrm{mM} \mathrm{NaCl}(\mathrm{pH}$ 7.4) to remove imidazole [14]. Protein concentration was determined by bicinchoninic acid (BCA) method, using bovine serum albumin (BSA) as standard. The dilution was freeze-dried and the final product stored at $-80^{\circ} \mathrm{C}$.

\section{SDS-PAGE and Western blot}

SDS-PAGE was performed in a $12 \% \mathrm{w} / \mathrm{v}$ polyacrylamide gel. Protein samples $(32 \mu \mathrm{l})$ were each mixed with $8 \mu \mathrm{l}$ of $5 \times$ SDS-PAGE loading buffer $(250 \mathrm{mM}$ Tris- $\mathrm{HCl}, 10 \%$ SDS, $0.5 \%$ bromophenol blue, $50 \%$ glycerol, $5 \% \beta-$ mercaptoethanol, $\mathrm{pH} 6.8$ ), and boiled at $100^{\circ} \mathrm{C}$ for $5 \mathrm{~min}$. The samples were loaded on a $12 \%$ SDS-polyacrylamide gel. The gels were stained with Coomassie Brilliant Blue R-250 and destained with the destain solution (2.5\% methanol, $10 \%$ acetic acid).

For Western blot, proteins were transferred onto a PVDF membrane after separation by $12 \%$ acrylamide gels. The membrane was blocked 
with $5 \%$ nonfat dry milk (NFDM) in Tris-buffered saline plus $0.1 \%$ tween 20 (TBST) overnight at 4 ${ }^{\circ} \mathrm{C}$. The blocked membrane was washed twice for $5 \mathrm{~min}$ in TBST and incubated with mouse anti-His $\operatorname{lgG}(1: 1000)$ for $2 \mathrm{~h}$ at $37{ }^{\circ} \mathrm{C}$. The membrane was washed three for $5 \mathrm{~min}$ in TBST. After washing, the membrane was incubated with HRP-labeled goat anti-mouse IgG (1:1000) for $1.5 \mathrm{~h}$ at $37^{\circ} \mathrm{C}$. The membrane was washed again with PBST. After a final wash of the membrane with TBST, the bands were revealed in films by ECL staining [15].

\section{Mass spectrometry}

The putative protein was identified by matrixassisted laser desorption/ionization time-of-flight mass (MALDI-TOF-MS) using an ABI 4800 plus MALDI-TOF/TOF Analyzer (ABI, USA). Sample was digested by sequencing grade modified trypsin (Promega), and then analyzed by the MALDI-TOF-MS using the ABI 4800 plus MALDITOF/TOF Analyzer. The result was searched against IPI database (V3.36) by GPS Explore software (V3.6, ABI, USA) and MASCOT (V2.1, Matrix Science, London, UK) $[14,16]$.

\section{Effects of metal ions on the activity of mSOD1 protein}

mSOD1 proteins were treated with various metal ions $\left(\mathrm{Na}^{+}, \mathrm{K}^{+}, \mathrm{Fe}^{2+}, \mathrm{Fe}^{3+}, \mathrm{Zn}^{2+}, \mathrm{Cu}^{2+}\right)$ for 10,20 , 30 and $40 \mathrm{~min}$ respectively (concentration of protein is $10 \mathrm{mg} / \mathrm{L}$, concentration of ion is $5 \mathrm{mM}$ ). mSOD1 proteins were treated with $\mathrm{Zn}^{2+}$ and $\mathrm{Cu}^{2+}$ of different ions concentration (concentration of ion: $0.05,0.5,5$ and $50 \mathrm{mM}$, respectively). mSOD1 proteins were treated with different temperature $\left(25,30,37\right.$ and $\left.50{ }^{\circ} \mathrm{C}\right)$ [17]. SOD activity assay kit was used to detect the activity of mSOD1.

\section{DNA nicking induced by hydroxyl radical}

DNA damage protective activity of mSOD1 was performed using super coiled pUC-19 DNA. The mSOD1 protein $(5-60 \mu \mathrm{g} / \mathrm{ml})$ was added to $6 \mu \mathrm{l}$ DNA $(0.5 \mu \mathrm{g})$ in a final volume of $10 \mu \mathrm{l}$. Experiments were conducted at room temperature for $10 \mathrm{~min}$. Then, $10 \mu \mathrm{l}$ of Fenton's reagent $\left(30 \mathrm{mM} \mathrm{H}_{2} \mathrm{O}_{2}, 50 \mu \mathrm{M}\right.$ ascorbic acid and $80 \mu \mathrm{M}$ of $\mathrm{FeCl}_{3}$ ) was added to the mixture of the mSOD1 and pUC-19 DNA. The final volume of mixture was made up to $20 \mu$ land incubated for $30 \mathrm{~min}$ at $37{ }^{\circ} \mathrm{C}$. The DNA was analyzed on $1 \%$ agarose gel using ethidium bromide staining and photographed in Gel Doc[18,19].

\section{Statistical analysis}

The experimental results were processed using Statistical Package for Sciences and Society (SPSS 12.0) (SPSS Inc, Chicago, IL, USA) and expressed as mean \pm SD (standard deviation) of triplicate measurements. The data were subjected to one-way analysis of variance (ANOVA) and the significance of differences between means was calculated. $p<0.01$ was considered highly significant. The software used was SigmaPlot 12 (Systat Software Inc).

\section{RESULTS}

\section{Construction of expression vector}

The fragment was inserted into pET15b (Sma I) vector, achieving recombinant plasmid pET15bmSOD1. Expected sizes of the recombinant plasmid constructs was confirmed by direct sequencing. The sequencing result indicated that the coding region of the mSOD1 gene was fused in-frame to upstream of the vector-derived His tag coding sequence successfully. Integration of DNA fragment amplifier and sequence analysis indicated that it encoded a mature mouse $\mathrm{Cu} / \mathrm{Zn}$ binding superoxide dismutase (mSOD1) protein with an estimated molecular mass of $20 \mathrm{kDa}$.

\section{Expression and purification of recombinant mSOD1 protein}

Cells were grown under several conditions of temperature and IPTG concentration to optimize protein expression. At $37{ }^{\circ} \mathrm{C}$, some protein was localized in the inclusion body fraction while almost all mSOD1 protein was obtained in the soluble fraction in cultures grown at $30{ }^{\circ} \mathrm{C}$ and induced by adding IPTG to a final concentration of $0.5 \mathrm{mM}[20]$. Cells were harvested by centrifugation. As shown in Fig 1A, an obvious band about $20 \mathrm{kD}$ of $\mathrm{mSOD} 1$ was visualized in the supernatant. The mSOD1 protein was almost in the supernatant of the lysis. According to the quantitative analysis, the percentage of the target protein in the supernatant of the lysis was about $40 \%$.

Availability of the expressed mSOD1 in the soluble fraction greatly facilitated its isolation and purification. In SDS-PAGE analysis, the protein migrated according to its predicted molecular mass. The purity was > $95 \%$ (Fig 1B). In addition, the process of purification was short and straightforward, because we purified soluble mSOD1 material directly after cell lysis without protein denaturing and refolding. 
The identity of purified target protein was confirmed by Western blot detection with anti-His tag antibody (Fig 1C).

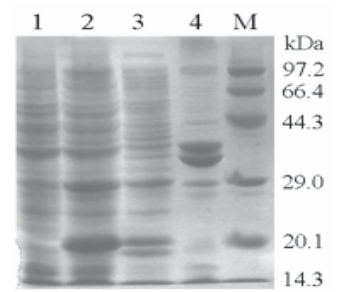

(A)

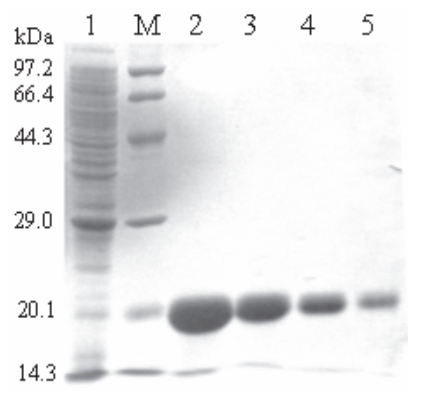

(B)

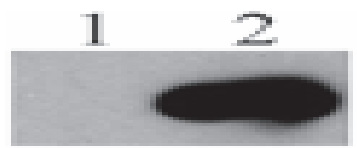

(C)

Figure 1: Expression and purification of mSOD1 protein; (A). Lanes 1, extract from the uninduced cell ; Lanes 2, extract from cells after IPTG induction; Lanes 3 and 4, supernatant and cell debris, respectively, obtained after centrifugation of the sonicated cells; $M$, Protein marker. (B) Lanes 1, flow-through; Lanes 2-5, four serial elution fractions; $M$, Protein marker (C) Western blot detection of fusion protein with anti-His $\mathrm{mAb}$. Lanes 1, cell lysate prior to induction; Lane 2, the sample after Ni-NTA affinity chromatography.

It showed that the finally expression quantity of mSOD1 was approximately $60 \mathrm{mg}$ target protein per liter of culture. The Table 1 summarizes the yield of mSOD1 during purification.

Table 1: Purification summary of mSOD1 protein from culture

\begin{tabular}{ccccc}
\hline $\begin{array}{c}\text { Purification } \\
\text { step }\end{array}$ & $\begin{array}{c}\text { Total } \\
\text { protein a } \\
(\mathbf{m g})\end{array}$ & $\begin{array}{c}\text { Purity } \\
(\%)\end{array}$ & $\begin{array}{c}\text { mSOD1 } \\
\text { (mg) }\end{array}$ & $\begin{array}{c}\text { Yield }^{\text {b }} \\
\text { (\%) }\end{array}$ \\
\hline $\begin{array}{c}\text { Soluble lysate } \\
\text { Ni-NTA affinity }\end{array}$ & 40.68 & 40.6 & 16.52 & 100 \\
chromatography & 12.53 & 95 & 11.90 & 72.03 \\
\hline
\end{tabular}

${ }^{a}$ Wet weight cells $(1.08 \mathrm{~g})$ from $200 \mathrm{ml}$ culture were lysed using sonication; ${ }^{b}$ Protein yield was calculated using the amount of $m S O D 1$ after concentration and mSOD1 amount in soluble lysate.

\section{Peptide masse fingerprinting (PMF) of mSOD1 protein}

To confirm the identity of the purified recombinant protein, the protein obtained after Ni-exchange chromatography was digested with trypsin and the resulting peptides were analysed by MALDI-TOF MS. A clear match between the mass of six generated peptides and the predicted peptides obtained from the mSOD1 protein sequence was observed (Fig. 2).

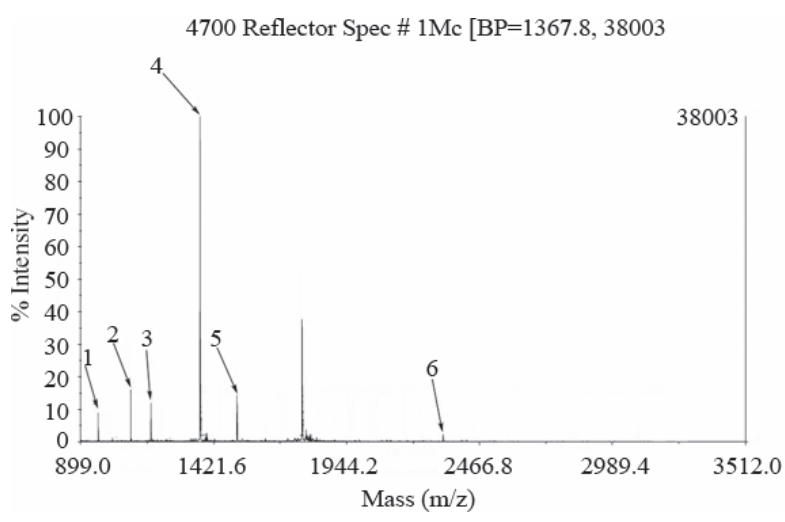

Figure 2: Identification of mSOD1 recombinant proteins by mass spectrometry analysis Peak 1 matched peptides of "HGGPADEER"; peak 2 matched peptides of "KHGGPADEER"; peak 3 matched peptides of "DGVANVSIEDR"; peak 4 matched peptides of "VISLSGEHSIIGR"; peak 5 matched peptides of "GDGPVQGTIHFEQK"; peak 6 matched peptides of "HVGDLGNVTAGKDGVANVSIEDR".

\section{Effect of metal ions on the activity of mSOD1 protein}

To determine the effects of metal ions on the activity of mSOD1 protein, mSOD1 was treated with different metal ions at the same concentration $(5 \mathrm{mM})$ in $37{ }^{\circ} \mathrm{C}$. Each reaction mixture was treated for $10,20,30$ and $40 \mathrm{~min}$. SOD activity assay kit was used to detect the activity of mSOD1. Among the activities of the various reaction mixtures, mSOD1 and $\mathrm{Zn}^{2+}$, $\mathrm{Cu}^{2+}$ and $\mathrm{Zn}^{2+} / \mathrm{Cu}^{2+}$ exerted greater effects on mSOD1 than the other ions $\left(\mathrm{Na}^{+}, \mathrm{K}^{+}, \mathrm{Fe}^{2+}\right.$ and $\left.\mathrm{Fe}^{3+}\right)$. The reaction mixture of mSOD1 and $\mathrm{Zn}^{2+} / \mathrm{Cu}^{2+}$ showed the highest activity. The mSOD1 activity was activated significantly by the metal ions of $\mathrm{Zn}^{2+} / \mathrm{Cu}^{2+}[17]$. The efficiency of $\mathrm{Zn}^{2+} / \mathrm{Cu}^{2+}$ for mSOD1 activation was about 10fold more potent than that of control. In addition, the activities of other reaction mixtures were improved minimally (Fig $3 \mathrm{~A}$ ).

We also found that the activity of mSOD1 improved with increase in metal ion concentration. The activity of mSOD1 was hardly improved when metal ion concentration exceeded $5 \mathrm{mM}$ (Fig 3B) [23]. As shown in Fig 
$3 \mathrm{C}$, temperature $\left(25-50{ }^{\circ} \mathrm{C}\right)$ had a small influence on the activity of mSOD1. Thus, the highest activity of the highest mSOD1 activity obtained was $3789.0 \pm 80.5 \mathrm{U} / \mathrm{mg}$, and it was obtained when it was treated with metal ion of $\mathrm{Zn}^{2+} / \mathrm{Cu}^{2+}(5 \mathrm{mM})$ at $37^{\circ} \mathrm{C}$ for $40 \mathrm{~min}$.

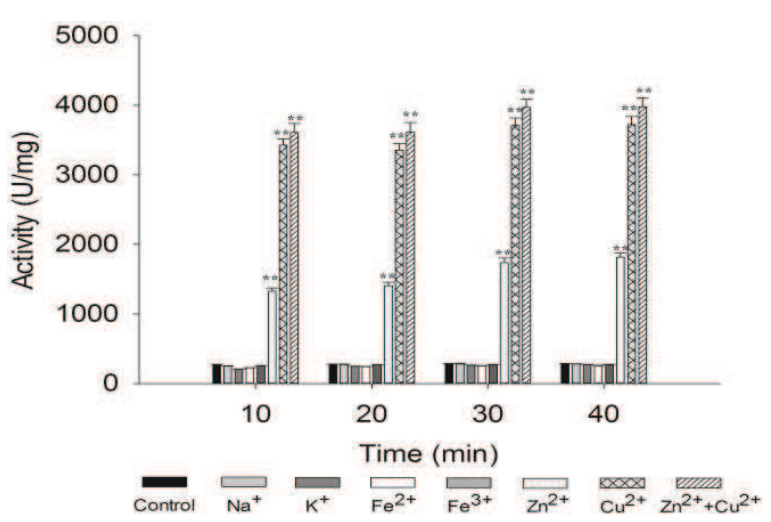

(A)

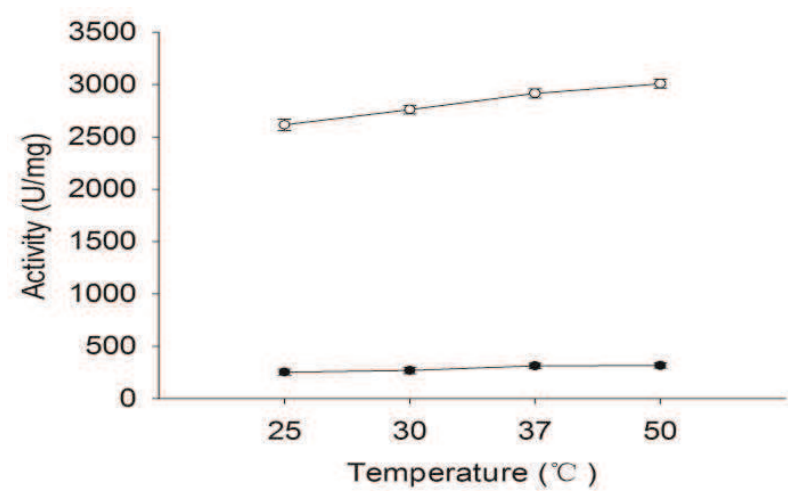

(B)

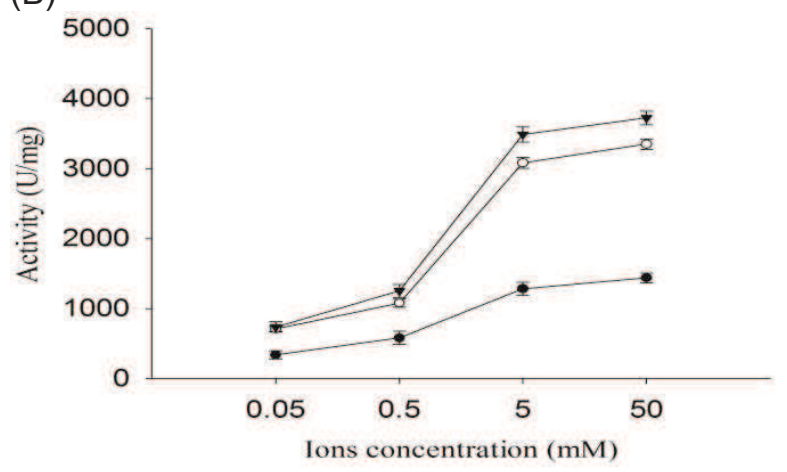

(C)

Figure 3: Effects of metal ions on the activity of protein mSOD1. (A) mSOD1s were treated with different ions for different time. The average data from three independent experiments. Statistically significant differences from the control in each group are indicated as ${ }^{* *} p<0.01$. (B) mSOD1s were treated with different ions concentration $\left(\mathrm{o}=\mathrm{Zn}^{2+}\right.$ and $\mathrm{Cu}^{2+}$, - =Control). (C) mSOD1s were treated with different temperature (Concentration of $\mathrm{mSOD} 1$ is $10 \mathrm{mg} / \mathrm{L}$, and concentration of ion is $5 \mathrm{mM}, \boldsymbol{\nabla}=\mathrm{Zn}^{2+}$ and $\mathrm{Cu}^{2+}$. $\left.\circ=\mathrm{Cu}^{2+}, \bullet=\mathrm{Zn}^{2+}\right)$.

\section{DNA damage protective activity of mSOD1}

Gel electrophoresis showed that the protection offered against DNA damage by mSOD1 (5 - 60 $\mu \mathrm{g} / \mathrm{ml}$ ) was concentration-dependent. At a concentration of $60 \mu \mathrm{g} / \mathrm{ml}$, protection was optimum and slightly close to that of native pUC19 DNA (Fig 4). mSOD1 showed effective and damage dependent reduction in the formation of nicked DNA and increased super coiled form of DNA.

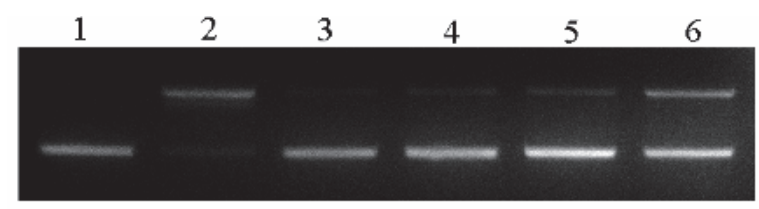

Figure 4: Effect of mSOD1 on oxidative DNA nicking caused by hydroxyl radicals. Lane 1, native pUC-19 DNA; Lane 2, DNA + Fenton's reagent; Lane 3- 6, DNA + Fenton's reagent + mSOD1 (60, 40, 20, 5 mg/L, respectively).

\section{DISCUSSION}

mSOD1 is one of the most important enzymes responsible for defense against oxidative damage due to ROS and particularly superoxide anion radicals. mSOD1 is strongly associated with and widely used in amyotrophic lateral sclerosis therapy. For these studies, a stable, purified mSOD1 is necessary. However, its use has been limited by its source. The activity investigation of mSOD1 mainly focused on in vivo, and especially related to amyotrophic lateral sclerosis. There are no reports on mSOD1 activity in vitro.

Here, we efficiently produced the genetically engineered mSOD1 protein, and also successfully developed and optimized a useful assay for determining the effect of metal ions on the activity of protein mSOD1. The present work showed that mSOD1 was effective in protecting oxidative DNA damage. ROS are highly toxic and might be generated by oxidative stress, such as DNA damage, lipid peroxidation, protein modification and other effects. All these symptoms manifest in various numerous diseases, including cancer, cardiovascular disease, diabetes, atherosclerosis, neurological disorders, chronic inflammation, etc [24]. This study will facilitate further in vitro and in vivo experimentation on mSOD1 as an antioxidant enzyme defense system against ROS and would be helpful in ameliorating diseases caused by DNA damage. mSOD1 may serve as a novel therapeutic for those diseases where the approach is to suppress oxidative stress. 


\section{CONCLUSION}

The structural gene of mSOD1 has been cloned in $\mathrm{pET}-15 \mathrm{~b}$ vector. High purity recombinant mSOD1 was obtained and characterized. We observed that the mSOD1 activity was significantly activated after treated with the metal ions of $\mathrm{Zn}^{2+}+\mathrm{Cu}^{2+}$. Furthermore, mSOD1 protein can protect DNA from damage induced by hydroxyl radical.

\section{ACKNOWLEDGEMENT}

This work was supported by grants from National Natural Science Foundation of China (30700704) and Key Laboratory of Regenerative Biology, Guangzhou Institute of Biomedicine and Health, Chinese Academy of Sciences (KLRB201105). \# The authors, ZZ and LH, contributed equally to this work.

\section{REFERENCES}

1. Hadji Sfaxi I, Ezzine A, Coquet L, Cosette P, Jouenne T, Marzouki MN. Combined Proteomic and Molecular Approaches for Cloning and Characterization of Copper-Zinc Superoxide dismutase (Cu, Zn-SOD2) from Garlic (Allium sativum). Mol Biotechnol 2012,52:49-58.

2. Chang LY, Slot JW, Geuze HJ, Crapo JD. Molecular immunocytochemistry of the CuZn superoxide dismutase in rat hepatocytes. J Cell Biol 1988, 107:2169-2179.

3. Liou W, Chang LY, Geuze HJ, Strous GJ, Crapo JD, Slot JW. Distribution of CuZn superoxide dismutase in rat liver. Free Radic Biol Med 1993, 14:201-207.

4. Bannister JV, Bannister WH, Rotilio G. Aspects of the structure, function, and applications of superoxide dismutase. CRC Crit Rev Biochem 1987,22:111180.

5. Youn HD, Kim EJ, Roe JH, Hah YC, Kang SO. A novel nickel-containing superoxide dismutase from Streptomyces spp. Biochem J 1996,318 ( Pt 3):889-896.

6. Wu TH, Liao MH, Kuo WY, Huang $\mathrm{CH}$, Hsieh HL, Jinn $T L$. Characterization of copper/zinc and manganese superoxide dismutase in green bamboo (Bambusa oldhamii): Cloning, expression and regulation. Plant Physiol Biochem 2011,49:195-200.

7. Lin CT, Lee TL, Duan KJ, Ken CF. Molecular cloning, characterization, and expression of a cDNA coding Copper/Zinc superoxide dismutase from black porgy. J Agric Food Chem 2000,48:4444-4447.

8. Lin CT, Lin MT, Chen YT, Shaw JF. Subunit interaction enhances enzyme activity and stability of sweet potato cytosolic Cu/Zn-superoxide dismutase purified by a His-tagged recombinant protein method. Plant Mol Biol 1995, 28:303-311.

9. Wei R, Bhattacharya A, Chintalaramulu $N$, Jernigan $A L$, Liu $Y$, Van Remmen $\mathrm{H}$, et al. Protein misfolding, mitochondrial dysfunction and muscle loss are not directly dependent on soluble and aggregation state of $m S O D 1$ protein in skeletal muscle of ALS. Biochem Biophys Res Commun 2012,417:12751279.
10. Thompson M, Marecki JC, Marinesco S, Labrie V, Roder JC, Barger SW, Crow JP. Paradoxical roles of serine racemase and D-serine in the G93A mSOD1 mouse model of amyotrophic lateral sclerosis. J Neurochem 2012,120:598-610.

11. Brown DR, Schulz-Schaeffer WJ, Schmidt B, Kretzschmar HA. Prion protein-deficient cells show altered response to oxidative stress due to decreased SOD-1 activity. Exp Neurol 1997, 146:104-112.

12. Amstad P, Peskin A, Shah G, Mirault ME, Moret R, Zbinden I, Cerutti $P$. The balance between copperzinc superoxide dismutase and catalase affects the sensitivity of mouse epidermal cells to oxidative stress. Biochemistry 1991,30:9305-9313.

13. Sheng H, Brady TC, Pearlstein RD, Crapo JD, Warner DS. Extracellular superoxide dismutase deficiency worsens outcome from focal cerebral ischemia in the mouse. Neurosci Lett 1999,267:13-16.

14. Feng W, Mei S, Wenjie Y, Luyuan H. High-level soluble expression of recombinant human manganese superoxide dismutase in Escherichia coli, and its effects on proliferation of the leukemia cell. Protein Expr Purif 2011,77:46-52.

15. Kim YI, Kim HJ, Kwon YM, Kang YJ, Lee IH, Jin BR, Han YS, Cheon HM, Ha NG, Seo SJ. Modulation of $M n S O D$ protein in response to different experimental stimulation in Hyphantria cunea. Comp Biochem Physiol B Biochem Mol Biol 2010,157:343-350.

16. Samyn B, Sergeant K, Memmi S, Debyser G, Devreese $B$, Van Beeumen J. MALDI-TOF/TOF de novo sequence analysis of 2-D PAGE-separated proteins from Halorhodospira halophila, a bacterium with unsequenced genome. Electrophoresis 2006, 27:2702-2711.

17. Kim JH, Cho H, Ryu SE, Choi MU. Effects of metal ions on the activity of protein tyrosine phosphatase VHR: highly potent and reversible oxidative inactivation by $\mathrm{Cu} 2+$ ion. Arch Biochem Biophys 2000,382:72-80.

18. Verma AR, Vijayakumar M, Rao CV, Mathela CS. In vitro and in vivo antioxidant properties and DNA damage protective activity of green fruit of Ficus glomerata. Food Chem Toxicol 2010,48:704-709.

19. Kim YG, Park HY. The effects of Pycnogenol on DNA damage in vitro and expression of superoxide dismutase and HP1 in Escherichia coli SOD and catalase deficient mutant cells. Phytother Res 2004, 18:900-905.

20. Yadaiah $M$, Nageswara Rao $P$, Sudhamalla $B$, Ramakrishna D, Mahammad Yasin U, Bhuyan AK. Cloning, Escherichia coli expression, purification, characterization, and enzyme assay of the ribosomal protein $\mathrm{S} 4$ from wheat seedlings (Triticum vulgare). Protein Expression and Purification 2012, 81:55-62.

21. Xiang $H$, Ishibashi $K$, Nishikiori $M$, Jaudal MC, Ishikawa $M$, Katoh E. Expression, purification, and functional characterization of a stable helicase domain from a tomato mosaic virus replication protein. Protein Expr Purif 2012,81:89-95.

22. Zhang $Y, X u T$, Chen Q, Wang B, Liu J. Expression, purification, and refolding of active human and mouse secreted group IIE phospholipase $A(2)$. Protein Expr Purif 2011,80:68-73.

23. Daosukho C, Ittarat W, Lin S, Sawyer D, Kiningham K, Lien Y, St Clair DK. Induction of manganese superoxide dismutase (MnSOD) mediates cardioprotective effect of tamoxifen (TAM). Journal of Molecular and Cellular Cardiology 2005,39:792803.

24. Jomova K, Valko M. Advances in metal-induced oxidative stress and human disease. Toxicology 2011,283:65-87. 